\title{
KEEFEKTIFAN ICE BREAKING DAN PROBLEM BASED LEARNING DALAM PEMBELAJARAN DIKELAS
}

\author{
Heni Purwa Pamungkas ${ }^{1 *}$, Mohamad Arief Rafsanjani ${ }^{2}$ \\ ${ }^{1,2}$ Universitas Negeri Surabaya \\ *E-mail: henipamungkas@unesa.ac.id
}

\begin{abstract}
Abstrak: Pembelajaran di era abad ke 21 berpusat pada peserta didik (student center learning). Pembelajaran diupayakan untuk membiasakan mahasiswa agar menjadi pebelajar sepanjang hayat (lifelong learning). Penelitian yang dilakukan bertujuan untuk mengetahui keefektifan ice breaking dan model Problem Based Learning dalam meningkatkan hasil belajar serta keaktifan mahasiswa dalam prose pembelajaran. Penelitian ini menggunakan pendekatan penelitian tindakan kelas dengan metode eksperimen. Dalam penelitian ini, ada dua kelas yang dibandingkan, yaitu: kelas kontrol dan kelas eksperimen dimana masing-masing kelas mendapatkan perlakuan (treatment) yang berbeda. Instrumen penelitian berupa lembar observasi keaktifan belajar, angket mahasiswa, serta soal pre test dan post test. Analisis data dilakukan secara kuantitatif deskriptif. Hasil penelitian menunjukkan bahwa terdapat perbedaan tingkat keaktifan belajar dan hasil belajar antara kelas control dengan kelas eksperimen. Selain itu, kenaikan hasil belajar di kelas eksperimen lebih besar dibandingkan kelas kontrol.
\end{abstract}

Kata Kunci: Ice Breaking, Problem Based Learning, Keaktifan Belajar, Hasil Belajar

\section{PENDAHULUAN}

Pembelajaran di abad ke-21 telah mengalami pergeseran paradigma. Saat ini pembelajaran diupayakan untuk mendorong mahasiswa agar aktif dalam menggali pengetahuan (student centered learning). Pergeseran paradigma ini menyebabkan perubahan pada proses belajar mengajar di kelas. Trilling, et.all (2015) menyatakan bahwa tuntutan abad ke-21 mensyaratkan sejumlah kompetensi diantaranya yaitu: keterampilan berpikir kritis (critical thinking skills), keterampilan berpikir kreatif (creative thinking skills, keterampilan berkolaborasi (collaboration skills), dan keterampilan berkomunikasi (communication skills). OECD (2008) menyatakan di kehidupan bermasyarakat saat ini kebutuhan menjadi seorang pebelajar sepanjang hayat tak terelakkan. Tuntutan terhadap tenaga kerja terdidik yang memiliki pemahaman konsep yang komprehensif serta kemampuan berpikir kreatif agar mampu menghasilkan ide-ide baru. Adanya tuntutan untuk memiliki karakter pebelajar sepanjang hayat (lifelong learning) serta keterampilan-keterampilan khusus tersebut, maka proses pembelajaran di kelas harus membiasakan mahasiswa agar aktif membangun pengetahuannya sendiri.

Dalam rangka membekali mahasiswa kependidikan agar siap menjadi tenaga pendidik di masa depan, maka mahasiswa perlu menempuh mata kuliah kependidikan. Mata kuliah Teori Belajar termasuk ke dalam kelompok mata kuliah 
yang wajib ditempuh mahasiswa pada program studi S1 Pendidikan Ekonomi. Mata kuliah Teori Belajar menjadi mata kuliah prasyarat bagi mata kuliah kependidikan lainnya. Capaian akhir dari mata kuliah Teori Belajar ialah agar mahasiswa menguasai teori-teori belajar yang efektif untuk pembelajaran ekonomi serta memiliki keterampilan untuk menerapkan teori-teori belajar yang efektif dalam melaksanakan pembelajaran ekonomi. Keterampilan inilah yang menjadi dasar bagi mahasiswa untuk menempuh mata kuliah kependidikan lainnya. Namun proses pembelajaran di mata kuliah ini masih jauh dari yang diharapkan. Hal ini tercermin pada saat proses perkuliahan, kurang dari 50\% mahasiswa terlibat aktif dalam proses diskusi sehingga pembelajaran masih didominasi dengan ceramah dari dosen. Sebagian besar mahasiswa cenderung pasif pada saat proses pembelajaran. Hal ini mengindikasikan bahwa keaktifan mahasiswa masih tergolong rendah. Akibatnya, proses pembelajaran tidak berjalan efektif, pengetahuan yang diterima mahasiswa tidak optimal serta rendahnya hasil belajar.

Dari observasi yang dilakukan dosen, diketahui bahwa durasi pembelajaran yang berlangsung cukup lama dan model pembelajaran yang monoton akan menyebabkan kebosanan pada mahasiswa. Hal ini menjadi penyebab suasana kelas tidak kondusif serta penyerapan infomasi mahasiswa tidak maksimal. Kurangnya motivasi belajar juga menjadi salah satu penyebab ketidakaktifan mahasiswa. Togia (2011) dalam penelitiannya menyatakan bahwa motivasi belajar berdampak pada hasil belajar kognitif. Untuk meningkatkan motivasi belajar, maka pendidik harus menggunakan strategi yang merangsang motivasi belajar. OECD (2008) menyatakan bahwa dalam pembelajaran abad ke 21 motivasi merupakan salah satu kunci sukses pebelajar dalam menuntut ilmu. Motivasi belajar dan kepercayaan terhadap kemampuan diri sendiri untuk menjadi pebelajar sepanjang hayat (lifelong learning). Sardiman (2012) menyatakan bahwa motivasi sangat berperan penting dalam menumbuhkan gairah dan semangat belajar. Hasil belajar akan maksimal apabila seseorang memiliki motivai belajar yang kuat.

Pembelajaran aktif merupakan suatu proses pembelajaran yang menuntut mahasiswa agar aktif dalam proses membangun pengetahuan. Tujuan dari penerapan pembelajaran aktif adalah untuk memaksimalkan seluruh potensi yang dimiliki oleh mahasiswa, sehingga mahasiswa memperoleh hasil belajar yang optimal. Selain itu, pembelajaran aktif juga memiliki tujuan menjaga perhatian mahasiswa agar tetap fokus pada saat proses belajar mengajar (PBM). Drake (2012) menyatakan bahwa pembelajaran aktif memiliki beberapa manfaat diantaranya adalah menciptakan pembelajaran bermakna dalam kelas. Pembelajaran bermakna akan maksimal apabila diorganisir dengan baik dan melibatkan aktivitas pebelajar dalam proses pembelajaran. Keterlibatan aktivitas yang dimaksud ialah kegiatan kognitif yang merangsang pebelajar untuk berpikir.

Salah satu bentuk dari pembelajaran aktif ialah penerapan model Problem Based Learning (PBL). Secara singkat, PBL dapat diartikan model pembelajaran yang mengacu pada pendekatan konstruktivistik dan memfasilitasi keterlibatan aktif peserta didik dalam proses memecahkan masalah. Konsep PBL berlandaskan pada teori pembelajaran aktif yang bermula dari konsep John Dewey dan teori konstruktivisme dari Jean Piaget. Susan (2018) menyatakan bahwa secara teoritis model PBL menggunakan masalah sebagai dasar untuk proses pembelajaran 


\section{KEEFEKTIFAN ICE BREAKING DAN PROBLEM BASED LEARNING DALAM PEMBELAJARAN DIKELAS}

merupakan salah satu strategi yang dapat meningkatkan pembelajaran aktif. Permasalahan yang digunakan dalam proses belajar merupakan awalan yang efektif untuk belajar karena dalam kehidupan sehari-hari mahasiswa dihadapkan dengan berbagai macam masalah. Lebih lanjut, pemilihan masalah yang diangkat sebagai bahan pembelajaran harus memberikan peluang bagi mahasiswa untuk membangun kemampuan memecahkan masalah. Warsono (2014) menyebutkan bahwa model pembelajaran PBL terdapat beberapa kelebihan diantaranya yaitu: siswa menjadi terbiasa menghadapi permasalahan serta mencari jalan keluar (solusi).

Namun, pembelajaran aktif akan gagal apabila mahasiswa tidak termotivasi dengan baik, pemberian contoh yang tidak memadai atau tidak relevan, atau ketika konsep tidak terintegrasi dengan pengetahuan mahasiswa saat ini. Oleh sebab itu, diperlukan inovasi dalam proses pembelajaran untuk menstimulasi motivasi dan keaktifan belajar mahasiswa. Hal ini dapat dilakukan dengan menerapakan ice breaking atau energizer. Secara sederhana, ice breaking dapat diartikan sebagai permainaan sederhana untuk melepas kepenatan dan mengembalikan konsentrasi mahasiswa. Belum banyak penelitian yang membahas kaitan ice breaking dalam pembelajaran. Chlup (2010) menyatakan bahwa esensi dari ice breaking adalah sebuah aktivitas yang didesain untuk mencairkan suasana serta mempererat hubungan antar peserta didik. Yeganehpour (2016) menyatakan bahwa ice breaking dapat dijadikan sarana untuk meningkatkan pembelajaran bermakna. Ice breaking juga dapat digunakan untuk meningkatkan motivasi belajar serta meningkatkan fokus peserta didik dalam megikuti proses pembelajaran. Ice breaking dapat digunakan sebagai kegiatan pembuka atau apersepsi sebelum mempelajar materi perkuliahan. Namun, penerapan ice breaking tidak selalu diawal pembelajaran, ice breaking dapat diterapkan ditengah maupun diakhir pembelajaran. Ice breaking dapat diterapkan sewaktu-waktu ketika dirasa suasana kelas tidak kondusif. Kelebihan dari ice breaking lainnya ialah penerapannya yang tidak membutuhkan waktu lama, sehingga tidak mengorbankan waktu perkuliahan.

Oleh sebab itu, agar terciptanya kegiatan belajar dan mengajar yang efektif maka mahasiswa perlu memiliki motivasi belajar yang tinggi. Penerapan ice breaker diawal perkuliahan bertujuan untuk mencairkan suasana kelas agar lebih kondusif, mempererat hubungan antar mahasiswa, serta menjadi apersepsi sebelum memasuki materi perkuliahan. Setelah mahasiswa siap menerima materi, Pembelajaraan dengan menggunakan model PBL akan membantu meningkatkan keaktifan mahasiswa. Tujuan dari penelitian ini ialah untuk mengetahui keefektifan kombinasi ice breaking dan PBL dalam pembelajaran dikelas.

\section{METODE}

Pendekatan penelitian yang dilakukan ialah penelitian tindakan kelas dengan metode eksperimen. Penelitian dilaksanakan sebanyak dua siklus dengan dua kali pertemuan di tiap siklusnya. Subjek penelitian adalah mahasiswa angkatan 2018 kelas A dan B Program Studi S1 Pendidikan Ekonomi Universitas Negeri Surabaya yang menempuh mata kuliah Teori Belajar. Adapun prosedur pelaksanaan penelitian ini berupa siklus yang terdiri dari tahap perencanaan (plan), pelaksanan (act), 
pengamatan (observe), dan refleksi (reflect). Gambaran siklus tersebut diilustrasikan pada gambar berikut ini.

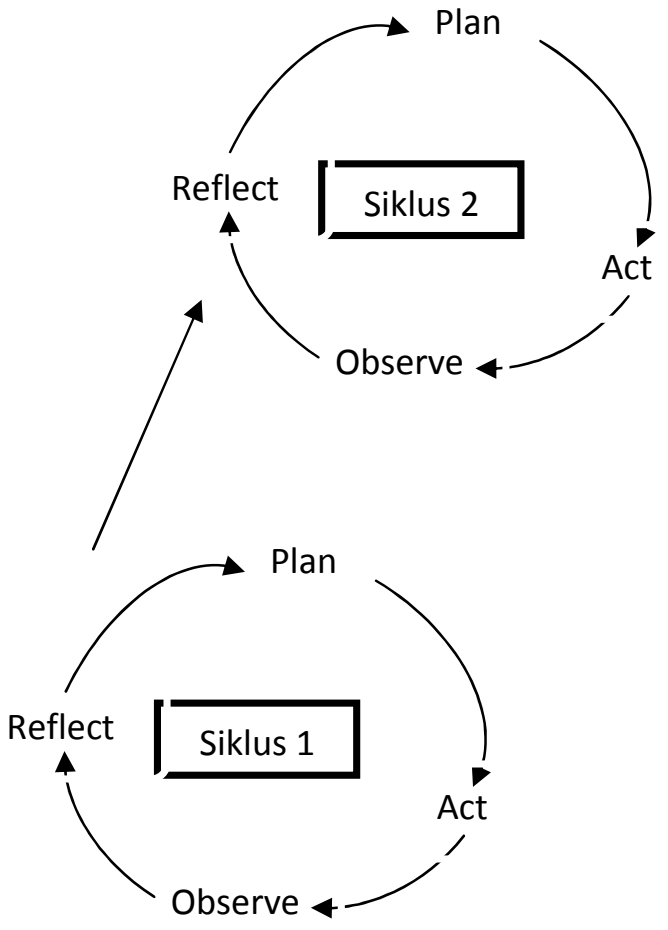

Gambar 1. Siklus PTK

Sumber: Herbert (2002)

Muliawan (2018) menyatakan bahwa ciri khas dari PTK adalah adanya siklus yang berulang-ulang. Tiap siklus memiliki tahapan berikut ini:

1) Perencanaan

Tahap ini merupakan tahapan dimana peneliti mempersiapkan rangkaian penelitian yang yang akan dilakukan meliputi penyusunan perangkat pembelaajaran, persiapan alat instrumen penelitian, serta hipotesa penelitian.

2) Pelaksanaan

Tahap pelaksanaan disebut juga sebagai tahap aplikasi. Tahapan ketika peneliti menerapkan pembelajaran PBL dan ice breaking di dalam kelas

3) Pengamatan

Tahap pengamatan ialah tahapan dimana observer melakukan pengamatan terhadap proses pembelajaran yang sedang berlangsung. Pada saat mengamati, observer berpedoman pada lembar observasi yang telah disusun.

4) Refleksi

Tahap refleksi ialah tahap dimana hasil pengamatan dianalisis dan disimpulkan dalam bentuk pernyataan-pernyataan teknis.

\section{Instrumen Penelitian}

Instrumen yang digunakan dalam penelitian ini, yaitu: 1) soal pretest dan posttest digunakan untuk mengetahui perbedaan hasil belajar mahasiswa, 2) angket respon mahasiswa terhadap penerapan ice breaking dan PBL, dan 3) lembar 


\section{KEEFEKTIFAN ICE BREAKING DAN PROBLEM BASED LEARNING DALAM PEMBELAJARAN DIKELAS}

observasi keaktifan mahasiswa untuk mengetahui tingkat keaktifan mahasiswa selama proses perkuliahan.

\section{Teknik Analisis Data}

Teknik analisis data dilakukan secara kuantitatif deskriptif yaitu dengan membandingkan serta menganalisis hasil nilai pretest dan posttest dari kelas eksperimen dan kelas kontrol, serta menganalisis angket dan lembar observasi keaktifan mahasiswa.

\section{HASIL DAN PEMBAHASAN}

Pelaksanaan PTK dilakukan selama dua siklus, dimana tiap siklus memiliki 2 kali tatap muka. Total keseluruhan pertemuan dalam penelitian sebanyak 4 kali. Masing-masing siklus diawali dengan pre test dan diakhiri dengan post test. Pemberian pre test dan post test dilakukan di kelas eksperimen serta kelas kontrol. Perbedaan antara dua kelas yang diujikan terletak pada metode pembelajaran yang diterapkan. Pada kelas eksperimen, proses pembelajaran menerapkan kombinasi ice breaking dan model PBL sedangkan model pembelajaran konvensional diterapkanpada kelas kontrol.

\section{Analisis Respon Mahasiswa}

Angket respon mahasiswa bertujuan untuk mengetahui respon mahasiswa terkait penerapan ice breaking dan model pembelajaran PBL dalam proses perkuliahan. Terkait penerapan ice breaking, terdapat 10 item pernyataan dengan menggunakan skala Likert. Opsi jawaban yang tersedia adalah SS (sangat setuju), S (setuju), KS (kurang setuju), TS (tidak setuju), dan STS (sangat tidak setuju). Berikut ini merupakan hasil dari respon mahsiswa terhadap pembelajaran dengan menggunakan kombinasi ice breaking dan PBL.

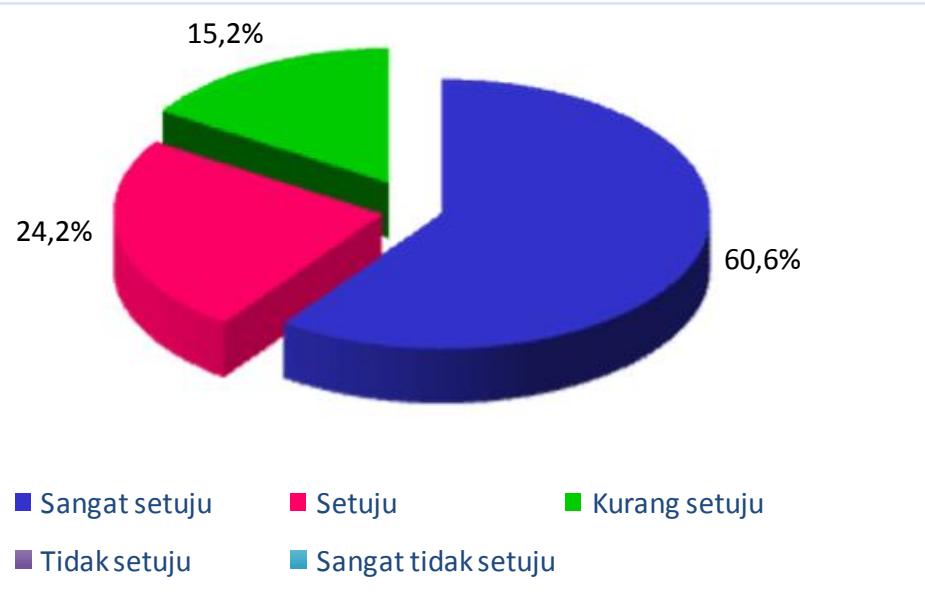

Gambar 2. Analisis Angket Respon Mahasiswa terhadap Pembelajaran dengan Menggunakan Ice Breaking dan model PBL

Secara umum dapat diketahui bahwa sebagian besar mahasiswa memberikan respon positif terhadap pembelajaran yang telah dilakukan. Hasil 
perhitungan angket menunjukkan persentase sebesar 60,6\% mahasiswa menyatakan sangat setuju bahwa kegiatan ice breaking di awal perkuliahan membantu mereka dalam meningkatkan konsentrasi dan minat belajar. 24,2\% mahasiswa menyatakan setuju dan hanya $15,2 \%$ mahasiswa menyatakan kurang setuju.

\section{Analisis Hasil Lembar Observasi}

Tingkat keaktifan belajar mahasiswa diukur melalui proses pengamatan yang dilakukan oleh observer berdasarkan item-item pernyataan pada lembar observasi. Pernyataan observasi terdiri dari 10 item dengan skala penilaian menggunakan opsi jawaban "ya" dan "tidak". Lembar observasi keaktifan mahasiswa digunakan untuk mengetahui peningkatan keaktifan mahasiswa selama 2 siklus. Observasi dilakukan di kelas eksperimen dan kelas kontrol agar dapat dibandingkan tingkat keaktifan mahasiswa dari kedua kelas tersebut. Dalam proses pembelajaran, observasi keaktifan mahasiswa dilakukan oleh dosen partner yang berperan sebagai observer. Dari hasil analisis lembar observasi, didapatkan rata-rata tingkat keaktifan mahasiswa dari kedua kelas tersebut. Berikut ini adalah perbandingan tingkat keaktifan mahasiswa pada kedua siklus.

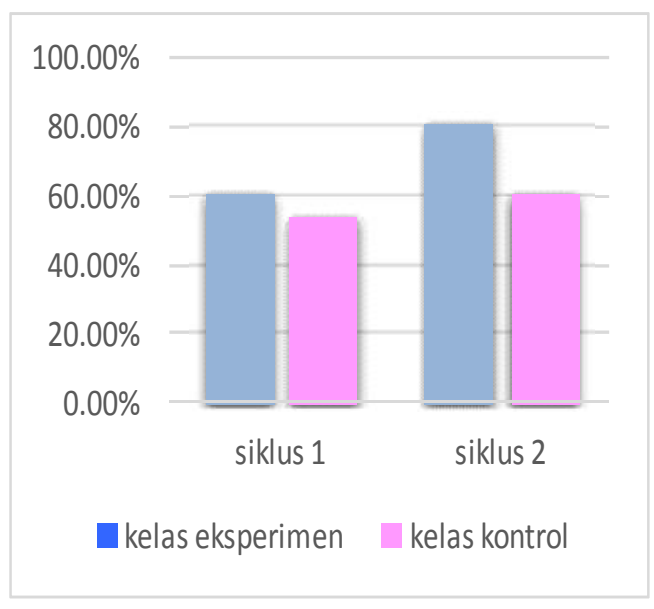

\section{Gambar 3. Tingkat Keaktifan Mahasiswa}

Tingkat keaktifan mahasiswa di dua kelas yang diujikan mengalami peningkatan. Namun, peningkatan keaktifan mahasiswa lebih tinggi di kelas eksperimen apabila dibandingkan dengan kelas kontrol. Pada kelas eksperimen, pada pertemuan di siklus pertama, tingkat keaktifan mahasiswa sekitar $61,4 \%$ kemudian di siklus kedua sebesar $81,5 \%$. Hal ini menunjukkan adanya kenaikan tingkat keaktifan belajar mahasiswa sekitar $20 \%$. Sedangkan di kelas control, pada siklus pertama tingkat keaktifan mahasiswa sebesar $57,5 \%$ sedangkan di siklus kedua hanya sebesar $61,5 \%$.

\section{Analisis Hasil Belajar}

Perbandingan hasil belajar didapatkan dari hasil pretest dan posttest. Kelas yang pertama (disebut sebagai kelas eksperimen) merupakan kelas yang menerapkan ice breaking dan PBL, sedangkan kelas kedua (disebut sebagai kelas 


\section{KEEFEKTIFAN ICE BREAKING DAN PROBLEM \\ BASED LEARNING DALAM PEMBELAJARAN \\ DIKELAS}

kontrol) merupakan kelas yang menerapkan pembelajaran klasikal. Hasil pretest dan posttest dari kedua kelas menunjukkan hasil yang berbeda. Tabel berikut merupakan hasil pretest dan posttest dari kedua kelas tersebut.

Tabel 1. Perbandingan nilai pre test dan post test

\begin{tabular}{lcccc}
\hline \multirow{2}{*}{ Kelas } & \multicolumn{2}{c}{ Siklus 1 } & \multicolumn{2}{c}{ Siklus 2 } \\
\cline { 2 - 5 } & Pre test & Post test & Pre test & Post test \\
\hline Eksperimen & 63,8 & 81,2 & 64,3 & 86,14 \\
& & & & \\
\hline Kontrol & 62,7 & 74,9 & 60,3 & 73,3 \\
\hline
\end{tabular}

Dari tabel diatas, diketahui bahwa kemampuan pada saat pre test diantara kedua kelas cenderung sama. Tetapi nilai post test menunjukkan hasil yang berbeda. Pada post test dikelas eksperimen pada siklus pertama sebesar 81,2 dan di kelas kontrol sebesar 74,9. Adanya peningkatan nilai rata-rata sebesar 17,4 pada kelas eksperimen serta 11,1 di kelas kontrol. Sedangkan pada siklus kedua, di kelas eksperimen terdapat peningkatan nilai sebesar 21,84 poin dan 13 poin untuk kelas kontrol. Dari paparan tersebut dapat disimpulkan bahwa penerapan ice breaking dan model PBL dapat meningkatkan keaktifan belajar yang pada akhirnya dapat mempengaruhi hasil belajar mahasiswa. Hasil penelitian ini mendukung penelitian terdahulu yang dilakukan oleh Kavanagh (2017) yang menyatakan bahwa penerapan ice breaking dapat meningkatkan soft skill mahasiswa dalam berkomunikasi,keterlibatan dalam kelas, serta motivasi mahasiswa. Hal ini menunjang pengalaman belajar mahasiswa dalam proses pembelajaran.

\section{SIMPULAN}

Dari hasil penelitian dapat disimpulkan bahwa penerapan kombinasi ice breaking dan model Problem Based Learning dapat meningkatkan keaktifan belajar mahasiswa. Hal ini dibuktikan dari hasil observasi keaktifan belajar yang semakin meningkat di tiap siklus. Pada siklus pertama, keaktifan belajar mahasiswa sekitar $61,4 \%$ dan di siklus kedua sekitar $81,5 \%$. Adanya peningkatan keaktifan belajar sebesar $20,1 \%$ akan berpengaruh pada meningkatnya hasil belajar mahasiswa. Selain itu, penerapan ice breaking di awal perkuliahan membantu mahasiswa meningkatkan konsentrasi dan minat belajar sedangkan penerapan model PBL menstimulus rasa ingin tahu mahasiswa, sehingga mahasiswa akan lebih aktif dalam proses pembelajaran.

\section{UCAPAN TERIMAKASIH}

Ucapan terimakasih ditujukan kepada Universitas Negeri Surabaya tempat dilakukannya penelitian dan juga Tim Jurnal Utility STKIP Nurul Huda. 


\section{REFERENSI}

Herbert Altrichter, Stephen Kemmis, Robin McTaggart, Ortrun Zuber-Skerritt, (2002) "The concept of action research", The Learning Organization, Vol. 9 Issue: 3 , pp.125-131, https://doi.org/10.1108/09696470210428840

Kavanagh, Marie, Marilyn Clark-Murph, Leigh Wood. (2011). The First Class: Using Icebreakers to FacilitateTransition in A Tertiary Environment. Asian Social Science, Vol. 7, No. 4, pp. 84-92

Muliawan, Jasa Ungguh. (2018). Penelitian Tindakan Kelas (Classroom Action Research). Yogyakarta: Penerbit Gava Media

OECD. (2008). $21^{\text {st }}$ Century Learning: Research, Innovation, and Policy. Paris: Centre for Educational Research and Innovation

Sardiman. (2012). Interaksi dan Motivasi Belajar Mengajar. Jakarta: Rajawali Pers

Susan Stetson-Tiligadas.(2018). Designing for Active Learning: A Problem-Centered Approach In Active Learning Strategies in Higher Education. https://doi.org/10.1108/978-1-78714-487-320181003

Togia, Aspasia, Stella Korobili, Afrodite Malliari. (2011). Motivation to Learn and Learning Strategies IT Courses In A Library and Information Science Department. Library Review, vol. 61 no. 1. DOI: https://doi.org/10.1108/00242531211207415

Trilling, Bernie, Peteer Nilsson, Jennifer Groff. (2015). Skills for the $21^{\text {st }}$ Century: What Should Students Learn?. Massachusetts: Center for Curriculum Redesign Warsono, Hariyanto. (2014). Pembelajaran Aktif. Bandung: PT Remaja Rosdakarya. Yeganehpour, Parisa. (2016). The Effect of Using Different Kinds of Ice- Breakers on Upper Intermediate Language Learners' Speaking Ability. The Journal of International Education Science. Vol. 3(6), pp. 217-238 